\title{
The Spillover and Transmission of Chinese Financial Markets Risk
}

\author{
Sha $\mathrm{Zhu}^{1,2}$ \\ ${ }^{1}$ Chinese Academy of Finance and Development, Central University of Finance and Economics, Beijing, China \\ ${ }^{2}$ School of Economics, Yunnan Uiniversity, Dianchi College, Yunnan, China \\ Correspondence: Sha Zhu, Chinese Academy of Finance and Development, Central University of Finance and \\ Economics, Beijing, China.
}

Received: June 11, 2018

doi:10.5539/ibr.v11n8p66

\author{
Accepted: June 27, 2018 \\ Online Published: July 19, 2018 \\ URL: https://doi.org/10.5539/ibr.v11n8p66
}

\begin{abstract}
After the 2008 financial crisis, the whole world financial markets became more fluctuates, the same to China also. It is necessary to pay great attention to high volatility problem in Chinese market, and also the uncertainty problem, risk accumulation and spillover effect come along with it. This paper calculates stock market return and builds financial stress index to explore the risk spillover effect. Empirical results show that the Chinese financial market have higher volatility than other countries. The Chinese stock market had higher dynamic market co-movement with international financial markets after 2008 financial crisis. What's more, this article also finds the financial risk spreads between China and US. When the US financial stress index increases, China's financial stress index experiences a larger increase. However, after the change in China's financial stress index, the US financial stress index has no obvious trend of change. So we should pay more attention to periods of Chinese financial market risk and its spillover.
\end{abstract}

Keywords: financial market risk; financial stress; spillover effect; risk transmission

\section{Introduction}

Since the global financial crisis in 2008, financial markets all over the world have suffered turbulence. Some economists hold the opinion that high volatility and rapid change will become the new norm for financial markets.

The reasons for the high volatility are complex. Since the financial crises, developed countries and emerging market economies tried to recover. However, it turned out nothing like they expected. As global political and economic environments keep changing, financial markets will be filled with uncertainty in the next few years or even farther into the future. There will be more dark horses, and high volatility will become a part of the global economic and financial world.

Economies of developed countries, especially the G7, are weighing less and less in the global economy, while emerging market economies are becoming more important. As an emerging market country, China is much more vulnerable to external shocks than developed countries, and its financial markets fluctuate more.

According to Chinese financial markets high fluctuation, the risks will spillover among China, US and another international countries. Financial spillovers are defined in this paper as the transmission of a risk shock in one country to asset prices in other countries. Financial spillovers in China could be transmitted to international financial markets through multiple channels, including international trade, price effects on tradable goods, financial flows, and even general market sentiment.

The main parts of this paper are organized by five sections. Section 2 shows the general review of financial risk in Chinese markets in by using Systematic Risk Index、VIX and stock market volatility. Section 3 and Section 4 shows the literature review and data description. Section 5 is the research methodology, including the DCC-GARCH model for stock market spillover effect and the construction of Chinese financial stress index for financial risk transmission. Section 6 is the empirical results of spillover effect and risk transmission.

\section{The General Review of Chinese Financial Markets}

\subsection{A General Review of Systematic Risk in Chinese Financial Market}

Brownlees and Eagle(2011) designed a systematic risk index(SRISK) from the aspect of insufficient funds and 
venture behavior in financial institutions, and then improved it in the same year. SRISK measures financial institution financing gap at the time when a systematic financial crisis happens. They calculate SRISK in this way

$$
\text { SRISK }_{\mathrm{i}, \mathrm{t}}=E_{t-1}\left(\text { Captial Shortfall }_{\mathrm{i}} \mid \text { Crisis }\right)
$$

This formula can be used to calculate how many funds a financial institution will need to keep it running during a global crisis, such as happened in 2008. From figure 1, we can see that although systematic risk has kept rising since 2000, its total level is still low. But since the economic crisis in 2007, the systematic risk appeared at a high level, along with a considerably higher volatility. SRISK has pointed out that global financial market structures have changed considerably, and high risk would be an ordinary condition of theglobal economy.

Risk Analysis Overview - All Financials Total SRISK (US\$ billion)

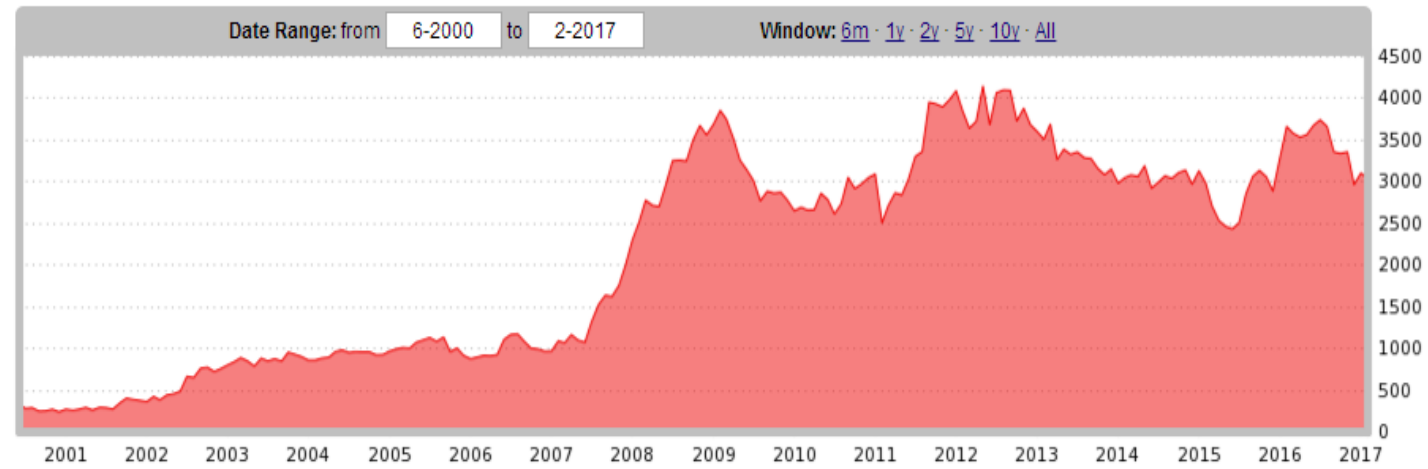

Figure 1. The total systematic risk of whole financial markets

Note. SRISK is calculated by Engle's team from VLAB. It's updated to 2017/2

Figure 2 below shows the systematic risks of some major financial markets in the world. As we can see, theChinese financial market has the greatest risk in the world. When a global economic crisis occurs, Chinese financial institutions will bear a loss of $\$ 700$ billion. After China, come Japan, France, British and USA. Of the top 10 countries at the greatest SRISK, only China comes from an emerging market.

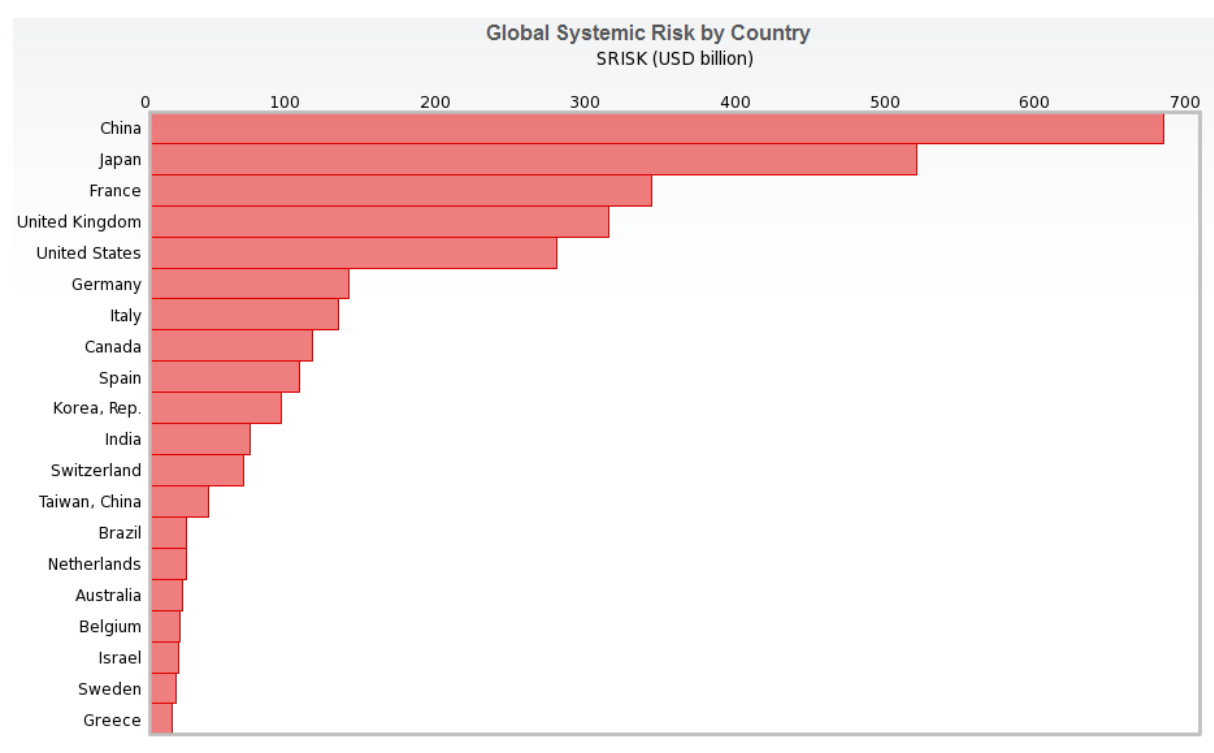

Figure 2. The rank of main international financial marketstotal SRISK

Note. SRISK is calculated by Engle's team from VLAB. It's updated to 2017/2

Figure 3 is systematic risk situation in China since 2008. We found that since financial crisis, systematic risk of Chinese market steeply rose. Although it dropped a lot in 2013 and 2015, it rose again in the last year 2016. 


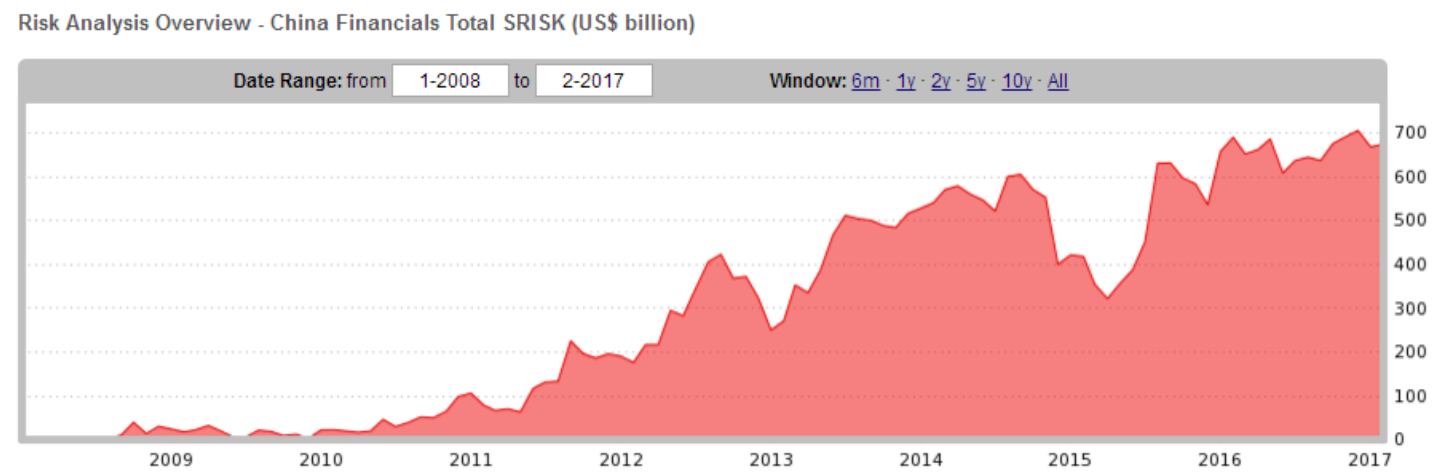

Figure 3. The total systematic risk in China

Note. SRISK is calculated by Engle's team from VLAB. It's updated to 2017/2

Although this method only includes total expected losses for the financial institutions and overlooks all other factors, it still is a valid way to calculate systematic risk, and illustrates a global impact. This analysis highlights high volatility in the Chinese markets, as well as shows uncertainty, risk accumulation and the spillover effect.. However, this topic is not just about the future development of China, but is also about global market stability.

\subsection{A General Review of Chinese VIX}

The VIX index is a measure of financial market volatility. It is also used to measure market risk and risk aversion levels of investors. A high VIX index makes investors leary of investing in the market; while a low VIX index stablilizes the market. The first chart below compares theVIX of the Chinese market with the American market and shows similar undulation trends and structures. In general, risk in the Chinese market is higher than risk in the US market. Chinese investors are more risk-averse than US investors. The second chart illustrates that in 2014, compared with all emerging markets, China market volatility and risk-aversion increased but followed other emerging market trends again by 2016 .
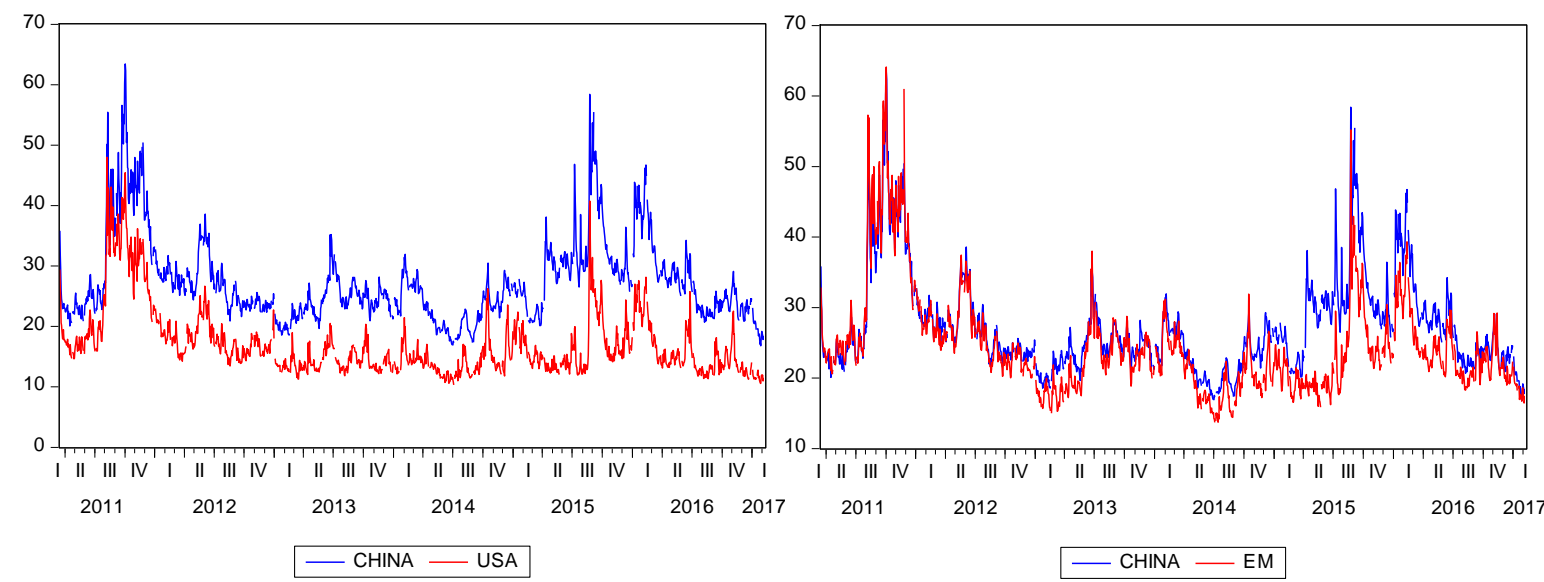

Figure 4. The volatility indices in China, US and Emerging Market

Note. Figure source: https://fred.stlouisfed.org/, sample period is from 2011/3/16 to 2017/2/10.

\subsection{A General Review of Chinese Stock Market Volatility}

According to stock market indices ( CSI 300 index , S\&P500 Index and MSCI index), the GARCH $(1,1)$ model is used to estimate the volatilities of three stock markets (China, US and Europe).Compared with US and Europe, the empirical results show these characteristics of stock volatilities in China:

1. Except during the 2008 financial crisis, China experiences higher volatility than other international financial markets.

2. The Chinese stock market experienced high volaitility and structural change in 2007 and again in 2014 . Specifically, volatility increased between 2007 and 2010. Then it dropped until 2014, when it surged up again.

3. The US and European markets fluctuated wildly from the end of 2008 to the beginning of 2009. Then 
they fell back quickly. In the middle of 2011, volatility increased again. Generally speaking, volatility of the American market is weaker than the European market.
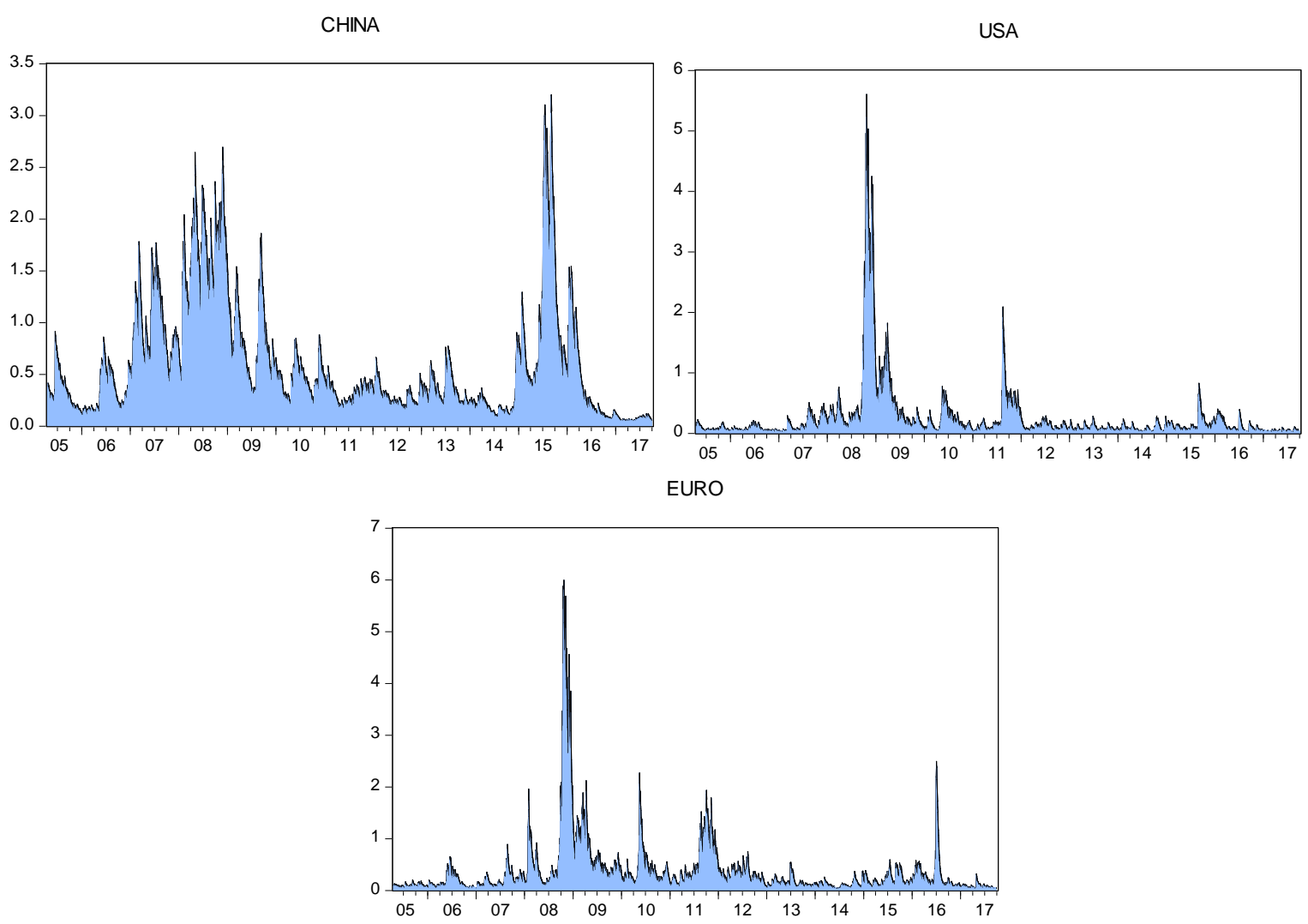

Figure 5. The volatility in international stock markets

\section{Literature Review}

Accurately determine the hidden dangers is the premise of ensuring financial security, we must accurately measure and effectively monitor the financial risk. The main measures of financial risk measurement are diverse. At the micro level, the mainstream indicators include the systematic expected loss value and the systematic risk indicator (named SES and SRISK, Acharya \& Robert Engle, 2012), and the delta of the conditional value at risk ( $\triangle$ CoVar, Adrian \& Brunnermeier, 2008). They can measure the marginal contribution of financial institutions to overall financial risk. In addition, there is the Joint Crisis Probability Approach (Segoviano \& Goodhart, 2009) which measures systematic risk across banks and portrays the interdependence of interbank risks. At the macro level, the mainstream methods are the composite index method and the early warning method (Frankel \& Rose, 1996; Kaminsky, Lizondo, \& Reinhart, 1998), which measures financial risk based on balance sheets and market data. This article needs to build a method that can fully reflect the China overall financial market risk and reflect its dynamic financial risk value. Therefore, this paper chooses the composite index method from the macro systematic risk level. The composite index approach is widely used and is especially important for developing countries that lack financial data. This method is feasible, continuity and flexibility. First, the method chooses various indicators related to financial market risk and then weights the indicators according to different weighting.

This paper uses the Financial Stress Index (FSI) to measure the systematic dynamic risk of financial market. It was first proposed by economists Illing and Liu (2003), which is a comprehensive index to estimate the macroeconomic financial pressure, through indicators of the four major financial markets (banking, stock market, bond market and foreign exchange market) measure risk and uncertainty. The IMF World Outlook Report (2008) using Cardarelli, Elekdagand, and Lall (2009), in which seven indicators were selected to measure the financial market risk by measuring the financial stress index of 17 developed countries to capture the corresponding stressful events. Empirical It is found that the financial stress index has a predictive effect on the real economy. Balakrishnan, Danninger, Elekdag, and Tytell (2011) selected five indicators to construct the stress index (EM-FSI) for 25 emerging market countries and used a two-stage model to verify the financial pressures linkage 
and spillover effects between in emerging market countries and developed countries. This method has been affirmed and adopted by IMF. Hakkio and Keeton (2009) chose 11 indicators to construct the Kansas City Stress Index (KCFSI), and selected more characteristic variables to measure the financial stress in U.S. cities. Subsequently, a large number of foreign literatures widely used the IMF (2008) measurement of financial stress indicators (short for AE-FSI) for developed countries and Balakrishnan (2011) measurement of financial stress indicators (short for EM-FSI) in emerging market countries.

In recent years, Chinese scholars have carried out research on financial stress analysis, most of them are the analysis of single financial market risk and stress testing, and the literature on the overall financial market stress measurement is relatively scarce. Juan Lai and Linjiang Lv (2010) selected four indicators of the four major markets of banks, foreign exchange, bonds and stocks to make preliminary estimates of the financial market pressures and were widely cite by scholars. However, in my opinion, the indicators chosen for the article and the widely used indicator system is quite different. Financial stress index were constructed by Xiaosing Liu and Lei Fang (2012), Shoudong Chen and Yan Wang (2011) and Guihuan Zheng (2014) by selecting from 7 to 10 indicators. In addition to the four major financial markets, they added the changes in insurance claims to measure financial stress in the insurance market. Dilong Xu and Shuanglian Chen (2015) based on the CRITIC weighting Law to build the financial stress index, add the real estate market to the new financial stress index. The literature places more emphasis on the impact of other markets on the risk of China's financial system rather than on financial markets itself, such as adding the real estate market and the insurance market.

\section{Data}

\subsection{Data Description and Statistics for Chinese Stock Market}

Data was collected from the CSI 300 beginning on April 8th, 2005 since it was not available prior to this date. Collection continued through October 10th, 2017 showing stock returns and volatility in the Chinese market The S\&P 500 index and MSCI index are used to measure the US and Europe markets respectively. The data used are all from Thomson Reuters DataStream. Figure 1 shows the three markets' stock indices in the sample period.
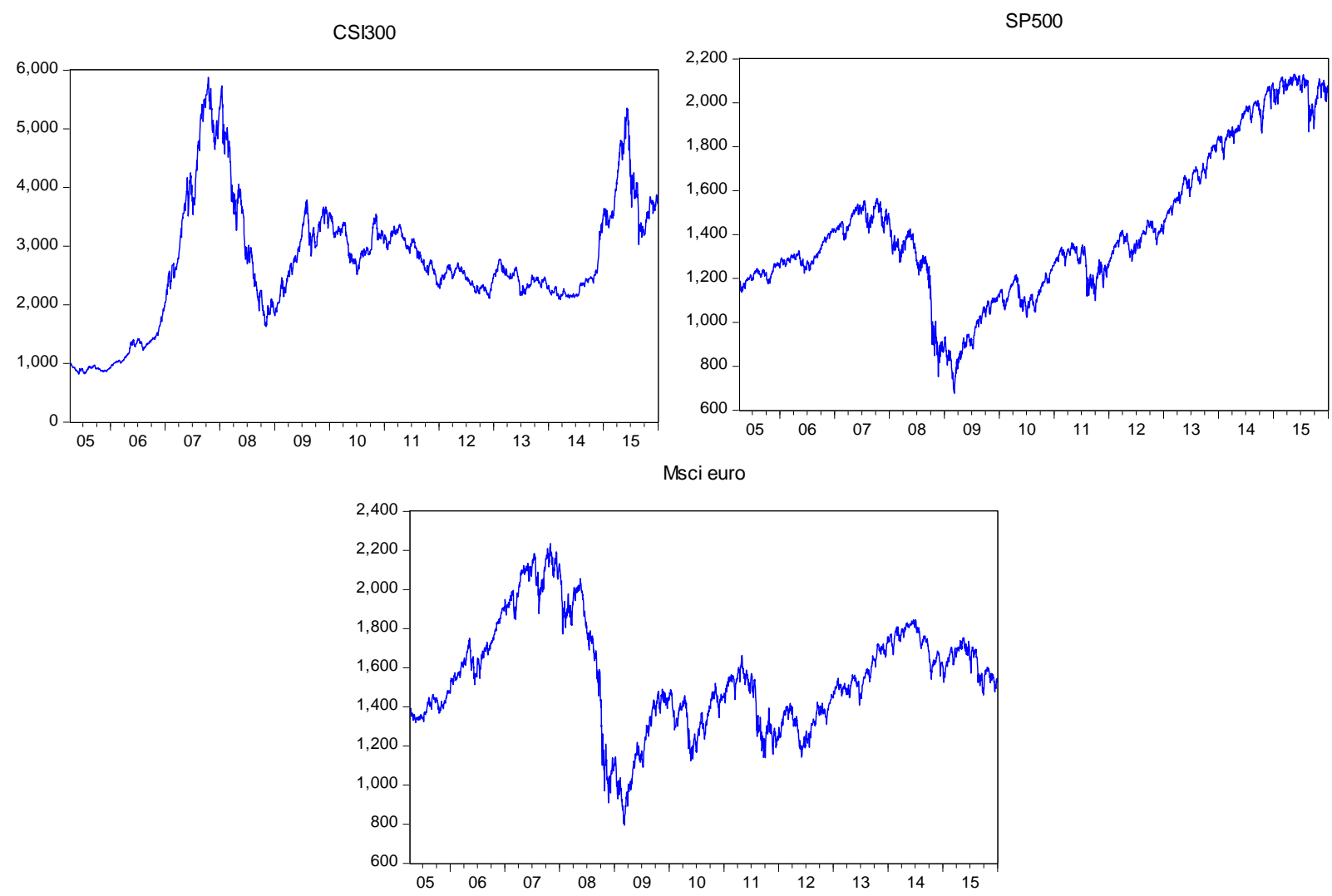

Figure 6. Three stock indices in the whole sample period

Daily closing prices are used to compute the stock returns. The stock returns can be denoted by $r_{t}=\left(\log \left(p_{t}\right)-\log \right.$ $\left.\left(\mathrm{p}_{\mathrm{t}-1}\right)\right) \times 100$, where $\mathrm{p}_{\mathrm{t}}$ is the stock index's closing price. Table 1 displays the summary statistics of indices for the stock daily returns in China, US and Europe. Calculations include the mean, median, maximum, minimum, 
standard deviation, skewness, and kurtosis of the stock returns over the whole sample period.

Table 1 . The statistics of indices daily return

\begin{tabular}{|c|c|c|c|}
\hline \multicolumn{4}{|c|}{ The statistics of indices daily return } \\
\hline & CHINA & US & EURO \\
\hline Observations & 3262 & 3262 & 3262 \\
\hline Mean & 0.018039 & 0.010249 & 0.003292 \\
\hline Median & 0.004686 & 0.015151 & 0.011179 \\
\hline Maximum & 3.87863 & 4.75865 & 4.646108 \\
\hline Minimum & -4.21056 & -4.11256 & -4.42036 \\
\hline Std. Dev. & 0.755799 & 0.515763 & 0.615778 \\
\hline Skewness & -0.55132 & -0.35605 & -0.17104 \\
\hline Kurtosis & 7.138536 & 15.25225 & 10.96824 \\
\hline
\end{tabular}

4.2 Data for Chinese Financial Stress Index

The core of the index system in this paper is the IMF Emerging Market stress Index System. The carefully chosen indicators for this paper are the rolling beta coefficient in the banking sector, the banking Ted spread, the term spread, the stock return, the volatility in the time-varying stock index, the sovereign bond spread, the devalued variables in currencies, and foreign exchange reserves.

Constructing the FSI using selected monthly data can reflect the financial market stress in time. This article selects monthly data from January 1997 to December 2016. The main data sources for this article are: Datastream, Resset, Wind, and CSMAR. In addition, the rolling $\beta$ coefficient and the time-varying stock index volatility $\left(\mathrm{h}_{t}\right)$ in the banking sector are respectively estimated by the author's establishment of the CAPM model and the GARCH $(1,1)$ model.

\section{Methodology}

\subsection{The DCC-GARCH Model for Three International Stock Markets}

Engle(2002) put forward the dynamic conditional correlation multivariate GARCH model, the conditional covariance matrix is decomposed into the conditional variance $\left(h_{i i, t}\right.$ and $\left.h_{j j, t}\right)$ and conditional correlation coefficient $\rho_{i j, t}$. The estimation process is divided into two steps: the first stage uses the original data and estimates a single variable GARCH equation for each sequence. The second step uses the first step's results to estimate the conditional variance of the dynamic correlation coefficient and the dynamic structure of $H_{t}$. In this paper, the DCC-GJR-GARCH model between three markets is as follows:

$$
\begin{gathered}
\text { First stage: } r_{i, t}=c_{i}+\varepsilon_{i, t} \quad i=1,2,3, \\
h_{i i, t}=\omega_{i}+\alpha_{i} \varepsilon_{i, t-1}^{2}+\beta_{i} h_{i i, t-1} \quad i=1,2,3,
\end{gathered}
$$

Second stage : estimation of the dynamic structure of $H_{t}$,

$$
\begin{aligned}
& H_{t}=D_{t} Q_{t} D_{t}=\left\{\rho_{i j, t} \sqrt{h_{i i, t} h_{j j, t}}\right\} \\
Q_{t}= & \left(1-\theta_{1}-\theta_{2}\right) \bar{Q}+\theta_{1} u_{t-1} u_{t-1}^{\prime}+\theta_{2} Q_{t-1}(13)
\end{aligned}
$$

Where $u_{i, t}=\varepsilon_{i, t} / \sqrt{h_{i i, t}}$ is the residual after standardization, $Q_{t}=\left\{q_{i j, t}\right\}$ is the conditional covariance matrix of $u_{t} . \bar{Q}=E\left[u_{t} u_{t}^{\prime}\right]$ is the unconditional variance matrix. $\rho_{i j, t}=\frac{q_{i j, t}}{\sqrt{q_{i i, t} q_{j j, t}}}, \theta_{1} \geq 0,, \theta_{2} \geq 0$, and $\theta_{1}+\theta_{2}<1$, i represents the three major financial markets ( $i=1$,China; $i=2$, America; i=3, Europe).

\subsection{The Construction of Chinese Financial Stress Index}

Scientific measurement of financial market risk, the choice of indicators of the system is very important. The core of the index system in this paper is the IMF Emerging Market stress Index System. We have made some specific calculations on the absence of important data on China financial markets, such as the rolling beta coefficient in the banking sector. For some selected indicators of the original data, we also make reference to the IMF's developed countries' stress index system and the financial stress index system released by other major banks, such as the St Louis Federal Financial Stress Index, with corresponding adjustments and additions. The carefully chosen indicators for this paper are the rolling beta coefficient in the banking sector, the banking Ted spread, the term spread, the stock return, the volatility in the time-varying stock index, the sovereign bond spread, the devalued variables in currencies, and foreign exchange reserves 8 Indicators, as described below. 
Table 2. Construction of Chinese Financial Stress Index

\begin{tabular}{|c|c|c|c|}
\hline $\begin{array}{c}\text { Markets } \\
\text { stress }\end{array}$ & Indicators & Calculation & Correlation \\
\hline \multirow[t]{3}{*}{ Banking stress } & Banking $\beta^{*}$ & $\begin{array}{l}\beta^{*}=\max \{\beta-1,0\}, \quad \mathrm{B} \text { is banking } \text { sector } \\
\text { rolling } \beta \text { coefficient. }\end{array}$ & Positive \\
\hline & BankingTed spread & $\begin{array}{l}\text { The } 3 \text {-month interbank offered rate minus the } \\
\text { risk-free rate }\end{array}$ & Positive \\
\hline & Term spread & $\begin{array}{l}\text { The difference between long-term government } \\
\text { bond yields ( } 10 \text { years }) \text { and short-term } \\
\text { government bond yields ( } 3 \text { months })\end{array}$ & Negative \\
\hline \multirow[t]{3}{*}{ Security market stress } & Stock return & $\begin{array}{l}\text { The monthly stock returns of the Shanghai } \\
\text { Composite Index }\end{array}$ & Negative \\
\hline & $\begin{array}{l}\text { Stockindex } \\
\text { volatilityH }_{t}\end{array}$ & $\begin{array}{l}\text { The stock index GARCH }(1,1) \text { model to } \\
\text { measure the dynamic volatility }\end{array}$ & Positive \\
\hline & $\begin{array}{l}\text { Sovereign } \\
\text { bondspread }\end{array}$ & $\begin{array}{l}\text { the difference between the yield on China's } \\
10 \text {-year bond and the yield on the United } \\
\text { States } 10 \text {-year bond }\end{array}$ & Positive \\
\hline \multirow[t]{2}{*}{ Exchange market stress } & Currency devaluation & The monthly exchange rate change & Positive \\
\hline & $\begin{array}{l}\text { Foreign exchange } \\
\text { reserves }\end{array}$ & $\begin{array}{l}\text { The monthly total national reserves minus the } \\
\text { change in the amount of gold reserves }\end{array}$ & Negative \\
\hline
\end{tabular}

The weight of FSI construction in this paper is based on the IMF construction method ---- equal weighted method. This method assumes that the variables $x_{i}$ follow a normal distribution after subtracting the mean $\overline{x_{l}}$, dividing by the standard deviation $\sigma_{x_{i}}$, taking the normalized variables by the same weight, and adding the subject variables below to represent the normalization of the corresponding variables. The total Financial Stress Index formulas are presented as follows:

$$
\mathrm{FSI}=\sum_{i=1}^{n} \frac{x_{i}-\overline{x_{l}}}{\sigma_{x_{i}}} \quad \mathrm{n}=8
$$

From January 1997 to December 2016 , the Chinese FSI constructed in this paper is shown below:

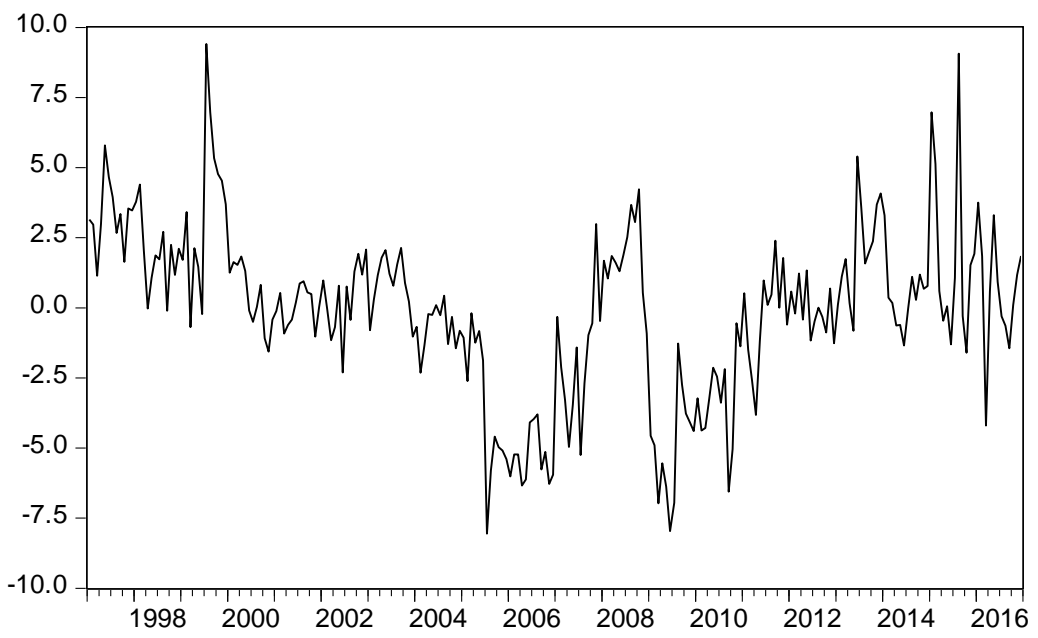

Figure 7. Chinese Financial Stress Index construction

\section{Empirical Results of Spillover Effect and Risk Transmission}

\subsection{The Spillover Effect of Chinese Stock Market}

Unexpected external events such as a financial crisis lead to stock market risk changes .At the same time, the change of the stock return's volatility induced by these events impact different financial markets, thus causing a spillover effect. When the financial risk increases suddenly, the cross market's financial risk contagion effect may occur among different financial markets. More importantly, because of intermarket correlation, the contagion effect varies among the different countries. Compared with the low correlation international stock markets, the high correlation stock markets' risk will be infected faster among each other, but low correlation stock markets' risk will be infected slower or not at all. In this paper, using DCC-GJR-GARCH model to explore the relationship among China, US and Europe, the.Chinese stock market is our main research focus. Initially, calculations of the stock markets' return were analyzed and then the multivariate GARCH model was used to verify the volatility spillover effect and dynamic conditional correlation among China and the other two major 
stock markets. A significant dynamic conditional correlation was found between China and the others markets.

Former researchers' work has proved that dynamic correlation coefficients of DCC-GARCH model can generally describe the correlation level of multiple markets across the world. Empirical results show a significant correlation between Chinese, European and American markets $\left(\theta_{1}=0.004 \mathrm{a} \theta_{2}=0.992, \theta_{1}+\theta_{2}<1\right.$, z-statistics are 2.32 and 214.9), proving a significant markets co-movement among these countries. This means when financial markets in one country have a sudden change, financial markets in other countries may be affected.

Additionally, markets co-movement also means infection among financial markets in different countries depend on their correlations. Different correlations can lead to various propagation speed and infectivity. In high correlation periods, market changes are more synchronized, with stronger interactivities, and high risk infection levels. In low correlation periods, market changes are less synchronized, with weaker interactivities, and lower risk infection levels. In other words, different correlations among markets can lead to different risk contagion results.

The results of this study also prove that the Chinese stock market had higher dynamic market co-movement than other international financial markets after 2008 financial crisis. When China entered to the "New Normal Period" in 2014, its interrmarket co-movement became lower suddenly, but then it rebounded again. What's more, the empirical research shows that China has higher correlation with Europe than the US. As a result, I consider that stock volatilities in international markets can affect Chinese financial risk significantly.
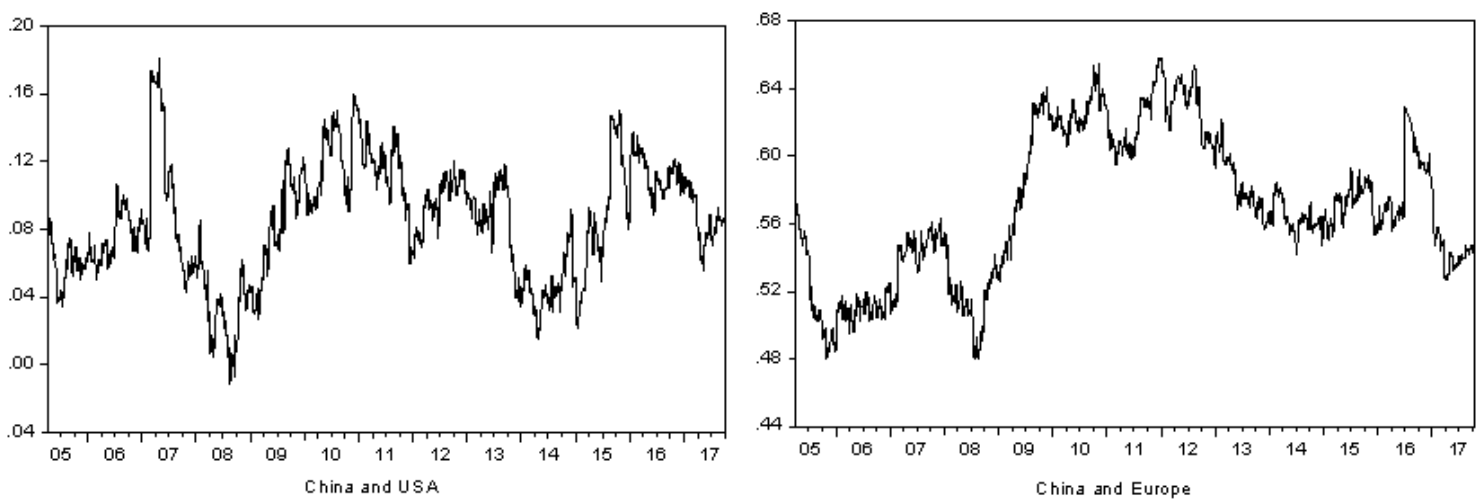

Figure 8. Stock markets dynamic correlation among China, US and Europe

\section{The Transmission of Risk in China-US Financial Markets}

Since China economic development gradually entered a "New Normal Period" from 2013, the banking industry, stock market and foreign exchange market have all shown the characteristics of a high financial risk state. Therefore, it is even more urgent to guard against the higher possibility of a new financial crisis for China. The Chinese government can't ignore financial market risk any more.In this paper, I build an index, called the Financial Stress Index (FSI), to calculate Chinese financial market risk. The FSI index constructed in this paper is forward-looking with real-time high-frequency data for the market. It covers the financial markets such as the stock market, bond market, foreign exchange market, and banking institutions. This index can measure the changes in the financial market risk in China.

As global economic integration continues to deepen, the financial market risk of various countries may have international contagion effect. As a center of the global economy, there may be a large spillover effect in the US financial market risk. This article uses the Financial Stress Index of the two countries (China and US), and constructs a VAR model to analyze whether there was a risk transmission mechanism between them. The following chart shows the financial stress index from January 1997 to December 2016 issued by the US St. Louis Fed. 


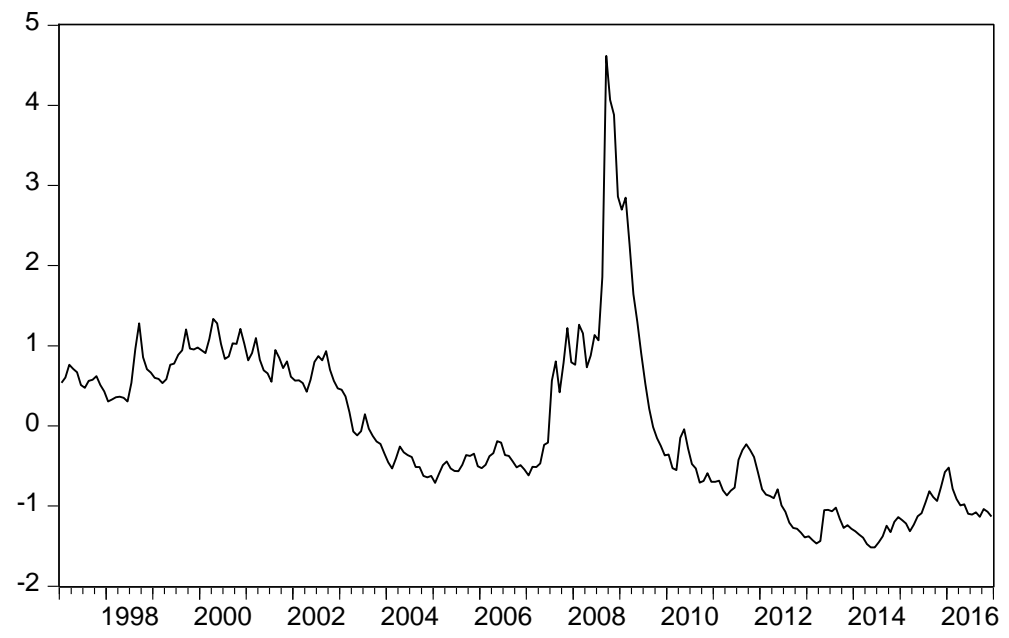

Figure 9. St. Louis Fed Financial Stress Index of US

\section{Note. FSI data from https://fred.stlouisfed.org/series/STLFSI}

This paper makes a Granger causal analysis of financial stress between the two countries and the results are shown in Table 3. The results show that the United States is China's Granger cause, but China is not the United States Granger cause. Figure 10 shows the results of the impulse response function. It can be seen that the US financial stress index is impacted by one unit of standard deviation, and China's financial stress index will have a larger increase. However, after the change in China's financial stress index, the US financial stress index has no obvious trend of change. From this we can see that the US financial market risk still has a stronger spillover effect on China.

Table 3. Granger Causality Analysis of Financial Market Risk in China and the US

\begin{tabular}{lcc}
\hline Null Hypothesis: & F-Statistic & Prob \\
\hline USFSI does not Granger Cause CFSI & 3.80106 & 0.0237 \\
CFSI does not Granger Cause USFSI & 1.19284 & 0.3052 \\
\hline
\end{tabular}

American FSI spillover to China

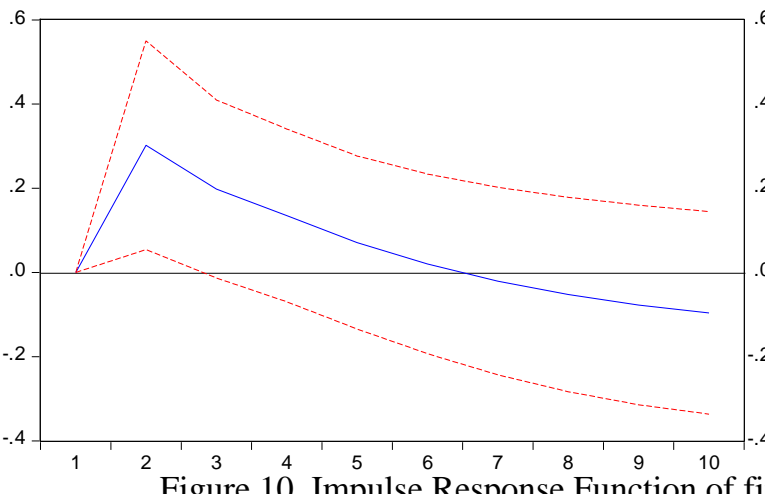

Figure 10. Impulse Response Function of financial market risk in China and US

Chinese FSI spillover to USA

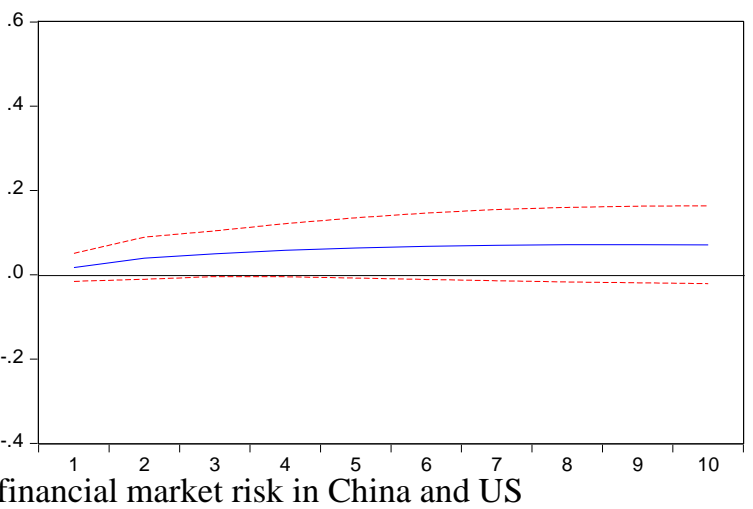

\section{Conclusions and Policy Suggestions}

First, the stock market in China can be affected by outside economic factors leading to sudden changes in the return rate of the stock market and increases in financial risk. Second, financial risk is able to spread across markets and impact financial assets prices in other countries, which will cause risk spillover effects. In extreme cases, it will lead to assets price fluctuations in the short term. Third, when financial markets are caught in turbulent periods, multiple country correlations may enhance the turbulence, and lead to systematic risk increases in a wider range, even causing global economic crises. Finally, US financial market risk has a strong spillover effect on China. US financial market risk has strong Granger cause on Chinese financial risk, but China does not impact US financial market risk similarly..

Based on these conclusions, the following Chinese policy proposals are suggested: 
- Realize the importance of systematic financial risk, a complete macro-prudence mechanism, and a stable financial market.

- Understand the relationship between international financial market risk and accumulation of systematic risk.

- Establish a pre-warning system for the possibility of crises.

- Pay more attention to the openness of the Chinese market and a higher correlation with other markets, limiting risk spillover.

\section{Acknowledgement}

Thanks to the co-author of the Drive Thru History America, Nita Thomason who gave me great help to correct my literature.

\section{References}

Acharya, V., Engle, R., \& Richardson, M. (2012). Capital shortfall: A new approach to ranking and regulating systemic risks. American Economic Review, 102(3), 59-64. https://doi.org/10.1257/aer.102.3.59

Adrian, T., \& Brunnermeier, M. (2008). Covar: A method for macro prudential regulation. Federal Reserve Bank of New York, Staff Reports: 348.

Balakrishnan, R., Danninger, S., Elekdag, S., \& Tytell, I. (2011). The transmission of financial stress from advanced to emerging economies. Emerging Markets Finance and Trade, 47(sup2), 40-68. https://doi.org/10.2753/REE1540-496X4703S203

Cardarelli, R., Elekdag, S., \& Lall, S. (2008). World Economic Outlook, October 2008: Financial Stress and Economic Downturns. World Economic and Financial Surveys (Washington: International Monetary Fund).

Forbes, K., \& Rigobon, R. (2002). No contagion, only interdependence: measuring stock market co-movements. Journal of Finance, 57(5), 2223-2261.

Frankel, J. A., \& Rose, A. K. (1996). A panel project on purchasing power parity: Mean reversion within and between countries. Journal of International Economics, 40(1-2), 209-224. https://doi.org/10.1016/0022-1996(95)01396-2

Hakkio, C. S., \& Keeton, W. R. (2009). Financial stress: What is it, how can it be measured, and why does it matter? Economic Review-Federal Reserve Bank of Kansas City, 94(2), 5.

Illing, M., \& Liu, Y. (2003). An index of financial stress for Canada. Bank of Canada Working Paper, No. 2003-14, Ottawa, June 2003.

Illing, M., \& Liu, Y. (2006). Measuring financial stress in a developed country: An application to Canada. Journal of Financial Stability, 2(3), 243-265. https://doi.org/10.1016/j.jfs.2006.06.002

IMF - International Monetary Fund. (2009). Global Financial Stability Report - Responding to the Financial Crisis and Measuring Systemic Risks. Washington, April.

Kaminsky, G., Lizondo, S., \& Reinhart, C. M. (1998). Leading indicators of currency crises. IMF Economic Review, 45(1), 1-48. https://doi.org/10.2307/3867328

Kenourgios, D., \& Dimitriou, D. (2015). Contagion of the global financial crisis and the real economy: a regional analysis. Economic Modelling, 2015(44), 283-293.

Segoviano, M. A., \& Goodhart, C. (2009). Banking stability measures. International Monetary Fund, IMF Working Papers: 09/4, 1-54.

\section{Copyrights}

Copyright for this article is retained by the author(s), with first publication rights granted to the journal.

This is an open-access article distributed under the terms and conditions of the Creative Commons Attribution license (http://creativecommons.org/licenses/by/4.0/). 